\title{
Biochemical Profile of Serbian Youth National Soccer Teams
}

\author{
Perfil Bioquímico de Equipos Juveniles de Fútbol Serbios
}

\author{
Aleksandar Joksimovic"; Marko Jezdimirovic*; Miroslav Smajic*; \\ Daniel Stankovic"; Stevo Popovic ${ }^{* * * *}$ \& Bogdan Tomic ${ }^{* * * *}$
}

JOKSIMOVIC, A.; JEZDIMIROVIC, M.; SMAJIC, M.; STANKOVIC, D.; POPOVIC, S. \& TOMIC, B. Biochemical profile of Serbian youth national soccer teams. Int. J. Morphol., 33(2):483-490, 2015.

SUMMARY: The aim of the present study was to determine biochemical profile of youth national soccer teams and to compare the values of nine biochemical parameters between three Serbian youth national teams (under 14, 15 and 16 years old), as well as between soccer players and non-athletes. Eighty young soccer players and thirty non-athletes participated in the study. Nine biochemical parameters (glucose, cholesterol, triglycerides, urea, creatinine, total bilirubin, AST (SGOT), ALT (SGPT), iron) were measured. In order to determine the significance of differences between the groups on a multivariate level a multivariate analysis of variance (MANOVA) was administered, and to test the differences between the groups on an univariate level a univariate analysis of variance (ANOVA) was applied. Statistically significant differences were found between groups (soccer players up to 14, 15 and 16 years of age) on a multivariate level of the applied biochemical variables (MANOVA, $\mathrm{p}=0.00)$. ANOVA also revealed significant differences in Creatinine $(\mathrm{p}=0.00)$, Total bilirubin $(\mathrm{p}=0.00)$ and ALT (SGPT) $(\mathrm{p}=0.02)$. Statistically significant differences in the applied variables were found between soccer players and non-athletes on a multivariate level (MANOVA $\mathrm{p}=0.00$ ). ANOVA also revealed significant differences in Glucose, Cholesterol, Triglycerides, Creatinine, Total bilirubin, ALT (SGPT) and Iron $(p=0.00)$ between soccer players and non-athletes, but there were no statistically significant differences in other variables (AST (SGOT) and Urea). It was concluded that there is significant difference in almost all variables (glucose, cholesterol, triglycerides, etc.), except AST (SGOT) and Urea between soccer players and non-athletes. From a practical point of view, the clinician has to take into account not only age, but also training status of individuals when evaluating their blood tests.

KEY WORDS: Biochemical parameters; Selection; Differences; Youth soccer.

\section{INTRODUCTION}

Soccer is one of the most widely played and complex sports in the world, where players need technical, tactical, and physical skills to succeed (Bjelica et al., 2013; Joksimovic et al., 2009). Soccer is characterized by a continuous course of activities with intermittent intensity of a game and a very low success ratio (the number of achieved goals) according to a possession of a ball (Reilly et al., 1993). For achieving top results in this sport and leading youth athletes to their real potential, it is necessary that players have an exceptionally high level of technical and tactical skills as well as significant physical preparedness (Svensson \& Drust, 2005; Domingues, 2013; Sarmento et al., 2014). Indeed, soccer is a team sport that is played in an outdoor field and requires a high standard of preparation through the development of physical performance skills, as well as tactical and technical expertise, in order to complete 90 minutes of competitive play (Popovic et al., 2012, 2013, 2014).

However, studies to improve soccer performance have often focused on technique and tactics at the expense of physical abilities such as endurance, strength, speed as well as physiological, mainly biochemical parameters (Joksimovic et al.). Technical and tactical skills in soccer are highly dependent on the player's physical capacity (Bangsbo, 1994; Hoff et al., 2002). During the last two decades, there has been significant accumulation of scientific data regarding soccer physiology and medicine. Previous investigations have evaluated ideal physiological and anthropometric profile of successful soccer players (Rhodes et al., 1986; Mangine et al., 1990; Davies et al., 1992). Athletes are usually monitored by using biochemical and

* University of Nis, Faculty of Sport and Physical Education, Nis, Serbia.

** University of Novi Sad, Faculty of Sport and Physical Education, Novi Sad, Serbia.

${ }^{* * *}$ University of Montenegro, Faculty for Sport and Physical Education, Niksic, Montenegro.

**** Sports Academy, Vjekoslava Kovaca, Belgrade, Serbia. 
hematological indices for evaluating possible pathologies and performance status (Dolci et al., 2007).

Creating top soccer players is a long-term process which includes identification, development and selection of the talents (Reilly et al., 2000) and the coach must be familiar with the model values of top soccer players in order to conduct proper selection and to design and implement training plan and programme (Milanovic et al., 2012). Because of that, the identification and development of young soccer players have become very important for the majority of the top-level teams (Williams \& Reilly, 2000) and a growing interest in improving the human performance of athletes is inherent (Micoogullari et al., 2012). The selection, development and professional guidance of young players is a priority for many top soccer clubs in order to maintain their sporting and financial status (Vaeyens et al., 2006). It is essential, however, to understand the key elements of talent identification and the development process for soccer (Martindale et al., 2005; Williams \& Franks, 1998). Given a lack of discrete objective measures of performance, as in individual sports, identifying soccer talent is complex and requires a multivariate approach (Hoare \& Warr, 2000; Williams \& Franks; Reilly et al., 2000). Potential predictors of soccer talent include anthropometric, physiological, neuromotor, cognitive-perceptual and psychosocial variables (Williams \& Franks). Evaluation of youth players is complicated by individual differences in the timing and tempo of changes in body size, functional capacities and motor efficiency during puberty (Malina et al., 2004; Philippaerts et al., 2006).

Numerous variables are taken into consideration when it comes to selection of the most qualitative young players, and all of them are being estimated with the help of various laboratory and field testing procedures. In addition to the fact that the significance of the testing is reflected in the evaluation of anthropological characteristics and efficiency training process assessment, probably the most important task of a continual monitoring is done by the selection of young people and monitoring the development of these categories of soccer players over a long period of time (Stojanovic, 2008). Therefore, scientists all over the world are looking for a standard formula that can improve the performance of elite players and discover talents as efficiently as possible (Popovic et al., 2013).

The aim of the present study was to determine biochemical profile of youth national soccer teams and to compare the values of nine biochemical parameters between 3 Serbian national teams (under 14, 15 and 16 years old) as well as between soccer players and non-athletes (control group).

\section{MATERIAL AND METHOD}

Research was performed on a sample of 80 young soccer players from 3 Serbian national teams (under 14-27 players, under $15-28$ players and under 16-25 players) and 30 non-athletes of the same age. To be included in the study, subjects had to meet the following criteria, which were assessed through the administration of a questionnaire: be in good health, with no known diseases, not use medications during the week preceding blood sampling, follow a regular diet, not use dietary supplements in excess of the recommended dietary allowances on a regular basis within the trimester preceding blood sampling, not use steroids or other banned substances. All participants were members of soccer clubs and had been training for the past three years or longer, at least 4 days per week, with training sessions lasting $1-1.5 \mathrm{~h}$.

Venous blood samples were collected into plain evacuated tubes from a forearm vein with minimal stasis after approximately $10 \mathrm{~min}$ of rest in a sitting position between 8 and 9 am, after an overnight fast and at least 24 hours from the last workout. An aliquot of each sample was immediately mixed with EDTA solution to prevent clotting for hematology. The rest of the sample was left to coagulate for $30 \mathrm{~min}$ at room temperature and was centrifuged at 1500 $\mathrm{x} \mathrm{g}$ for $10 \mathrm{~min}$ in order to separate the serum for chemistry. The serum was stored at $-20^{\circ} \mathrm{C}$.

We measured 9 biochemical parameters glucose, cholesterol, triglycerides, urea, creatinine, total bilirubin, AST (SGOT), ALT (SGPT), iron. The biochemical parameters were measured in a Hitachi 902, Roche/Hitachi (Japan) blood chemistry analyzer. The biochemical measurements were generally performed within 3 hours.

The value of a biochemical parameter pertaining to an individual will be referred to as a reference value, according to the terminology of the International Federation of Clinical Chemistry (Gräsbeck et al., 1978). Because some participants visited the laboratory more than once, they had more than one reference value for a certain parameter. In that case, we selected the median for statistical analysis.

Statistical methods applied were: Descriptive statistics comprised: number of subjects $(\mathrm{N})$, mean value (Mean), standard deviation (SD), minimum (Min) and maximum (Max) numerical results, range (Range) and standard error of the mean value (Error). Discriminative measurements were performed by two procedures: Skewniss (SKEW) pointing to the symetry of substance layout around arithmetic mean and Kurtosis (KURT) designating 
peakedness or flatness of distribution. In order to determine the significance of differences between the groups on a multivariate level amultivariate analysis of variance MANOVA was administered, and to test the differences between the groups on an univariate level univariate analysis of variance ANOVA was administered. Statistica 8.0. software program was used to process data.

\section{RESULTS}

A review of the results of the central and dispersion parameters of the applied biochemical variables of the selected soccer players up to 14 years of age (U-14), up to 15 years of age (U-15) and up to 16 years of age (U-16) it

Table I. Basic statistical parameters of soccer players U-14, U-15 and U-16.

\begin{tabular}{|c|c|c|c|c|c|c|c|c|c|}
\hline Variables & Group & Mean & Min & Max & Range & SD & Error & Skew & Kurt \\
\hline \multirow[t]{3}{*}{ Glucose } & U-14 & 4.985 & 4.000 & 6.000 & 2.000 & 0.618 & 0.119 & -0.017 & -1.003 \\
\hline & $\mathrm{U}-15$ & 5.118 & 4.000 & 6.000 & 2.000 & 0.564 & 0.107 & -0.407 & -0.288 \\
\hline & U-16 & 5.136 & 4.000 & 6.000 & 2.000 & 0.563 & 0.113 & -0.635 & 0.002 \\
\hline \multirow[t]{3}{*}{ Cholesterol } & $\mathrm{U}-14$ & 3.785 & 2.900 & 4.800 & 1.900 & 0.513 & 0.099 & 0.033 & -0.382 \\
\hline & $\mathrm{U}-15$ & 3.757 & 2.900 & 4.700 & 1.800 & 0.444 & 0.084 & 0.526 & 0.089 \\
\hline & U-16 & 3.832 & 2.700 & 4.600 & 1.900 & 0.512 & 0.102 & -0.450 & -0.231 \\
\hline \multirow[t]{3}{*}{ Triglycerides } & U-14 & 0.585 & 0.410 & 0.970 & 0.560 & 0.149 & 0.029 & 1.146 & 0.681 \\
\hline & $\mathrm{U}-15$ & 0.674 & 0.340 & 1.430 & 1.090 & 0.259 & 0.049 & 1.191 & 1.377 \\
\hline & U-16 & 0.684 & 0.210 & 1.460 & 1.250 & 0.247 & 0.049 & 1.112 & 3.344 \\
\hline \multirow[t]{3}{*}{ Urea } & U-14 & 4.567 & 3.300 & 6.400 & 3.100 & 0.962 & 0.185 & 0.549 & -0.877 \\
\hline & $\mathrm{U}-15$ & 4.086 & 2.600 & 6.300 & 3.700 & 0.888 & 0.168 & 0.863 & 0.865 \\
\hline & U-16 & 4.144 & 2.700 & 5.900 & 3.200 & 0.971 & 0.194 & 0.281 & -0.801 \\
\hline \multirow[t]{3}{*}{ Creatinine } & U-14 & 81.444 & 58.000 & 99.000 & 41.000 & 10.364 & 1.995 & -0.287 & -0.219 \\
\hline & U-15 & 93.357 & 71.000 & 116.000 & 45.000 & 12.200 & 2.306 & 0.087 & -0.608 \\
\hline & U-16 & 91.080 & 76.000 & 110.000 & 34.000 & 9.734 & 1.947 & 0.343 & -0.575 \\
\hline \multirow[t]{3}{*}{ Total bilirubin } & U-14 & 7.033 & 4.000 & 9.600 & 5.600 & 1.547 & 0.298 & 0.083 & -0.877 \\
\hline & $\mathrm{U}-15$ & 8.350 & 4.200 & 14.600 & 10.400 & 2.423 & 0.458 & 0.259 & 0.242 \\
\hline & U-16 & 9.672 & 5.100 & 16.600 & 11.500 & 3.538 & 0.708 & 0.865 & -0.111 \\
\hline \multirow[t]{3}{*}{ AST (SGOT) } & U-14 & 21.593 & 12.000 & 30.000 & 18.000 & 4.405 & 0.848 & -0.078 & -0.565 \\
\hline & U-15 & 23.786 & 11.000 & 43.000 & 32.000 & 7.857 & 1.485 & 0.840 & 0.421 \\
\hline & U-16 & 26.160 & 17.000 & 49.000 & 32.000 & 7.803 & 1.561 & 1.303 & 1.885 \\
\hline \multirow[t]{3}{*}{ ALT (SGPT) } & U-14 & 16.741 & 9.000 & 27.000 & 18.000 & 4.703 & 0.905 & 0.286 & -0.513 \\
\hline & U-15 & 18.857 & 11.000 & 32.000 & 21.000 & 5.421 & 1.024 & 0.930 & 0.497 \\
\hline & U-16 & 21.400 & 10.000 & 39.000 & 29.000 & 7.411 & 1.482 & 0.587 & -0.158 \\
\hline \multirow[t]{3}{*}{ Iron } & U-14 & 17.563 & 10.600 & 28.000 & 17.400 & 4.632 & 0.891 & 0.638 & -0.199 \\
\hline & U-15 & 20.371 & 13.000 & 26.600 & 13.600 & 4.426 & 0.836 & -0.144 & -1.295 \\
\hline & U-16 & 18.888 & 11.000 & 29.600 & 18.600 & 3.844 & 0.769 & 0.350 & 1.470 \\
\hline
\end{tabular}

Table II. Basic statistical parameters of soccer players (all 3 groups).

\begin{tabular}{lcccccccc}
\hline Variables & Mean & Min & Max & Range & SD & Error & Skew & Kurt \\
\hline Glucose & 5.079 & 4.000 & 6.000 & 2.000 & 0.579 & 0.065 & -0.329 & -0.660 \\
Cholesterol & 3.790 & 2.700 & 4.800 & 2.100 & 0.485 & 0.054 & 0.011 & -0.388 \\
Triglycerides & 0.647 & 0.210 & 1.460 & 1.250 & 0.225 & 0.025 & 1.333 & 2.665 \\
Urea & 4.266 & 2.600 & 6.400 & 3.800 & 0.953 & 0.107 & 0.525 & -0.392 \\
Creatinine & 88.625 & 58.000 & 116.000 & 58.000 & 11.936 & 1.334 & 0.078 & -0.099 \\
Total bilirubin & 8.319 & 4.000 & 16.600 & 12.600 & 2.782 & 0.311 & 1.172 & 1.733 \\
AST (SGOT) & 23.788 & 11.000 & 49.000 & 38.000 & 7.029 & 0.786 & 1.153 & 1.902 \\
ALT (SGPT) & 18.938 & 9.000 & 39.000 & 30.000 & 6.130 & 0.685 & 0.876 & 0.704 \\
Iron & 18.960 & 10.600 & 29.600 & 19.000 & 4.429 & 0.495 & 0.222 & -0.635 \\
\hline
\end{tabular}


can be said that the distribution in the zones around arithmetic mean (Skew) is optimal in most variables (Table I). From Skewness one can also notice that there are somewhat higher results of arithmetic mean in Triglycerides in all three groups, and AST in soccer players up to 16 years of age. However Kurtosis (Kurt.) whose value in almost all variables is significantly smaller than 2.75 points to the fact that distribution differs from the normal one (platikurtic distribution) which means that the test results are quite scattered. This comes as no surprise, because the tested soccer players were the ones playing on different positions (defense players, midfielders, forwards and goalkeepers). A little bit narrow distribution is in variable triglycerides in U16.

Table III. Basic statistical parameters of non-athletes.

\begin{tabular}{lcccccccc}
\hline Variables & Mean & Min & Max & Range & SD & Error & Skew & Kurt \\
\hline Glucose & 5.423 & 4.100 & 6.100 & 2.000 & 0.496 & 0.091 & -0.892 & 0.354 \\
Cholesterol & 5.272 & 4.100 & 7.100 & 3.000 & 0.710 & 0.130 & 0.607 & -0.044 \\
Triglycerides & 1.559 & 1.000 & 3.000 & 2.000 & 0.397 & 0.072 & 1.686 & 4.765 \\
Urea & 4.625 & 1.600 & 7.800 & 6.200 & 1.461 & 0.267 & -0.018 & 0.156 \\
Creatinine & 79.000 & 65.000 & 96.000 & 31.000 & 8.094 & 1.478 & 0.083 & -0.435 \\
Total bilirubin & 11.327 & 6.800 & 15.300 & 8.500 & 2.456 & 0.448 & -0.142 & -0.984 \\
AST (SGOT) & 24.660 & 16.300 & 35.800 & 19.500 & 4.868 & 0.889 & 0.271 & -0.189 \\
ALT (SGPT) & 23.163 & 11.400 & 43.400 & 32.000 & 8.899 & 1.625 & 0.949 & 0.032 \\
Iron & 15.143 & 10.100 & 22.600 & 12.500 & 2.862 & 0.523 & 0.509 & 0.158 \\
\hline
\end{tabular}

Table IV. Multivariate differences between U-14, U-15 and U-16.

\begin{tabular}{lccccc}
\hline Test & Value & F & Effect - df & Error - df & p \\
\hline Wilks & 0.518421 & 2.981 & 18 & 138 & $\mathbf{0 . 0 0 0 1 5 8}$ \\
\hline
\end{tabular}

Table V. Univariate differences between U-14, U-15 and U-16.

\begin{tabular}{|c|c|c|c|c|c|}
\hline Variables & Group & Mean & SD & $\mathbf{F}$ & $\mathbf{p}$ \\
\hline \multirow[t]{3}{*}{ Glucose } & U-14 & 4.985 & 0.618 & 0.5320 & 0.5895 \\
\hline & U-15 & 5.118 & 0.564 & & \\
\hline & $U-16$ & 5.136 & 0.563 & & \\
\hline \multirow[t]{3}{*}{ Cholesterol } & U-14 & 3.785 & 0.513 & 0.1562 & 0.8557 \\
\hline & $U-15$ & 3.757 & 0.444 & & \\
\hline & U-16 & 3.832 & 0.512 & & \\
\hline \multirow[t]{3}{*}{ Triglycerides } & U-14 & 0.585 & 0.149 & 1.5838 & 0.2118 \\
\hline & U-15 & 0.674 & 0.259 & & \\
\hline & U-16 & 0.684 & 0.247 & & \\
\hline \multirow[t]{3}{*}{ Urea } & U-14 & 4.567 & 0.962 & 2.1074 & 0.1285 \\
\hline & U-15 & 4.086 & 0.888 & & \\
\hline & U-16 & 4.144 & 0.971 & & \\
\hline \multirow[t]{3}{*}{ Creatinine } & $\mathrm{U}-14$ & 81.444 & 10.364 & 9.1952 & 0.0003 \\
\hline & U-15 & 93.357 & 12.200 & & \\
\hline & $\mathrm{U}-16$ & 91.080 & 9.734 & & \\
\hline \multirow[t]{3}{*}{ Total bilirubin } & U-14 & 7.033 & 1.547 & 6.6808 & 0.0021 \\
\hline & $\mathrm{U}-15$ & 8.350 & 2.423 & & \\
\hline & U-16 & 9.672 & 3.538 & & \\
\hline \multirow[t]{3}{*}{ AST (SGOT) } & U-14 & 21.593 & 4.405 & 2.8700 & 0.0628 \\
\hline & U-15 & 23.786 & 7.857 & & \\
\hline & U-16 & 26.160 & 7.803 & & \\
\hline \multirow[t]{3}{*}{ ALT (SGPT) } & U-14 & 16.741 & 4.703 & 4.0422 & 0.0214 \\
\hline & U-15 & 18.857 & 5.421 & & \\
\hline & U-16 & 21.400 & 7.411 & & \\
\hline \multirow[t]{3}{*}{ Iron } & U-14 & 17.563 & 4.632 & 2.9009 & 0.0610 \\
\hline & U-15 & 20.371 & 4.426 & & \\
\hline & $\mathrm{U}-16$ & 18.888 & 3.844 & & \\
\hline
\end{tabular}


Here are shown the results of the central and dispersive parameters of all soccer players - all three groups (Table II). By analyzing it one can notice that the distribution of the data is symmetric (Skew.) and scattered (Kurt.) in most variables. Skewness can show that the slightly right-oriented distribution can be seen only in variables of triglycerides, Total bilirubin and AST, and in variables of Triglycerides Kurtosis shows normal distribution, and a quite scattered distribution in all the other variables.

Here are shown the results of the central and dispersive parameters of non-athletes (Table III). By analyzing it one can notice that the distribution of the data is symmetric (Skew.) and scattered (Kurt.) in most variables. The distribution in the zones around arithmetic mean (Skew.) is optimal in most variables except in the variable triglycerides. Kurtosis (Kurt.) whose value in almost all

Table VI. Multivariate differences between soccer players and non-athletes

\begin{tabular}{cccccc}
\hline Test & Value & F & Effect - df & Error - df & p \\
\hline Wilks & 0.194168 & 46.113 & 9 & 100 & $\mathbf{0 . 0 0 0 0 0 0}$ \\
\hline
\end{tabular}

Table VII. Univariate differences between soccer players and non-athletes.

\begin{tabular}{|c|c|c|c|c|c|c|}
\hline Variables & Group & $\mathbf{n}$ & Mean & SD & $\mathbf{F}$ & p \\
\hline \multirow{2}{*}{ Glucose } & Soccer plrs. & 80 & 5.079 & 0.579 & \multirow{2}{*}{8.3202} & \multirow{2}{*}{0.0047} \\
\hline & Control & 30 & 5.423 & 0.496 & & \\
\hline \multirow{2}{*}{ Cholesterol } & Soccer plrs. & 80 & 3.790 & 0.485 & \multirow{2}{*}{156.0014} & \multirow{2}{*}{0.0000} \\
\hline & Control & 30 & 5.272 & 0.710 & & \\
\hline \multirow{2}{*}{ Triglycerides } & Soccer plrs. & 80 & 0.647 & 0.225 & \multirow{2}{*}{228.6897} & \multirow{2}{*}{0.0000} \\
\hline & Control & 30 & 1.559 & 0.397 & & \\
\hline \multirow{2}{*}{ Urea } & Soccer plrs. & 80 & 4.266 & 0.953 & \multirow{2}{*}{2.2696} & \multirow{2}{*}{0.1349} \\
\hline & Control & 30 & 4.625 & 1.461 & & \\
\hline \multirow{2}{*}{ Creatinine } & S occer plrs. & 80 & 88.625 & 11.936 & \multirow{2}{*}{16.5944} & \multirow{2}{*}{0.0001} \\
\hline & Control & 30 & 79.000 & 8.094 & & \\
\hline \multirow{2}{*}{ Total bilirubin } & Soccer plrs. & 80 & 8.319 & 2.782 & \multirow{2}{*}{27.1093} & \multirow{2}{*}{0.0000} \\
\hline & Control & 30 & 11.327 & 2.456 & & \\
\hline \multirow{2}{*}{ AST (SGOT) } & Soccer plrs. & 80 & 23.788 & 7.029 & \multirow{2}{*}{0.3908} & \multirow{2}{*}{0.5332} \\
\hline & Control & 30 & 24.660 & 4.868 & & \\
\hline \multirow{2}{*}{ ALT (SGPT) } & S occer plrs. & 80 & 18.938 & 6.130 & \multirow{2}{*}{7.9922} & \multirow{2}{*}{0.0056} \\
\hline & Control & 30 & 23.163 & 8.899 & & \\
\hline \multirow{2}{*}{ Iron } & S occer plrs. & 80 & 18.960 & 4.429 & \multirow{2}{*}{19.2027} & \multirow{2}{*}{0.0000} \\
\hline & Control & 30 & 15.143 & 2.862 & & \\
\hline
\end{tabular}

variables is significantly smaller than 2.75 points, which means that the test results are quite scattered except in variables of triglycerides, where a very narrow distribution is shown.

Results of multivariate differences of the applied biochemical variables (Table IV) between three groups of subjects (selections of soccer players up to 14,15 and 16 years of age). Analyzing it one can say that there are statistically significant differences in the applied variables between these groups on a multivariate level $(\mathrm{p}=0.000158)$.

Analyzing results which shows univariate differences of the applied biochemical variables (Table V) between three groups of subjects (U-14, U-15 and U-16) it can be concluded that statistically significant difference is present in variables creatinine, total bilirubin and ALT (SGPT). In all other variables there are no statistically significant differences (glucose, cholesterol, triglycerides, urea, AST (SGOT) and Iron).

Results of multivariate differences of the applied biochemical variables (Table VI) between soccer players and nonathletes. Analyzing it one can say that there are statistically significant differences in the applied variables between soccer players and non-athletes on a multivariate level $(\mathrm{p}=0.000000)$.

Analyzing results which shows univariate differences of the applied biochemical variables (Table VII) between soccer players and non-athletes it can be concluded that statistically significant difference is present in variables glucose, cholesterol, triglycerides, creatinine, Total bilirubin, ALT (SGPT) and iron. In other variables there are no statistically significant differences (AST (SGPT) and urea). 


\section{DISCUSSION}

Sport and exercise scientists engaged in soccer research are interested in a multitude of factors that determine the performance of a player as well as the related underlying phenomena that explains how each factor influences that performance. Biochemical tests are used widely to access health and fitness of the intensively training athlete (Drust et al., 2007; Nikolaidis et al., 2003).

The reference values usually listed in laboratory reports have been calculated on sedentary people and may not be useful for sports people. Athletes are, by definition, healthy and "normal" subjects, but they often show - owing to physical exercise, training, psychophysical stress, and peculiar environmental conditions - some biochemical, hormonal, and haematological values that are out of range. This particular behaviour of laboratory values must be properly interpreted to avoid incorrect treatment, expensive examinations, and possible cessation of training and competition (Banfi, 2006).

In our study significant difference is present in variables creatinine, total bilirubin and ALT (SGPT) in all three study groups. In all other variables there are no statistically significant differences.

The results in present study show us statistically significant difference in variables glucose between soccer players and non-athletes. Athletes had significantly higher glucose concentrations than nonathletes, respectively, despite the rigid homeostatic control mechanism operating in blood (Bates et al., 1997). The difference between athletes and non-athletes disagrees with (Crespo et al., 1995), who found no differences, but agrees with (LeBlanc et al., 1983). Whether repeated exercise bouts affect the homeostatics mechanism of glucose is a matter that requires further examination.

In this study soccer players had significantly lower cholesterol and triglycerides concentrations than non-athletes. Concerning the effect of physical activity, we found a slightly better lipid profile in athletes compared to non-athletes, as evidenced by the significantly lower concentrations of cholesterol and triglycerides (Nikolaidis et al.). Similar findings regarding cholesterol and triglycerides were reported in reviews on children and adolescents (Tolfrey et al., 2000), as well as adults (Durstine et al., 2001).
We have found significantly higher creatinine values in soccer players compared to non-athletes. The most pronounced effect on creatinine exerted by physical activity, with all groups of soccer players exhibiting significantly higher levels than non-athletes. The higher levels of athletes are apparently due to the exercise sessions preceding blood sampling, since creatinine activity peaks 1-2 days after exercise and remains elevated for several days (Noakes, 1987). Results similar to ours been reported by some authors (Rotenberg et al., 1988).

The present study showed significant increase in total bilirubin and ALT (SGPT) between soccer players and non-athletes. Low total bilirubin levels may be related with dysregulation of insulin signaling (Lin et al., 2009). Results similar to ours have been reported by some authors (Banfi). ALT and AST are widely distributed in tissues and are detected in serum of humans due to their release from damaged cells. ALT is mainly a marker of liver disease, while an increase in AST is more specific to muscle cell disruption and the condition of overtraining (Noakes).

Soccer players had significantly higher iron values than non-athletes. An additional reason for the higher values in soccer players may be the preceding intensive training. Most of the relevant studies agree with our findings, reporting similar levels between trained and untrained (Malczewska et al., 2000; Weight et al., 1992).

\section{CONCLUSION}

In conclusion, the knowledge of differences in biochemical parameters between young soccer players and non-athletes should provide useful information for the clinical assessment of an athlete. Therefore, from a practical point of view, the clinician has to take into account not only age, but also training status of individuals when evaluating their blood samples. Adequate and timely monitoring of blood parameters represents one of the most important measurements for preventing overtraining state. To prevent the appearance of the overtraining symptoms in sports, continuous monitoring of aerobic and anaerobic parameters of well training is necessary. 
JOKSIMOVIC, A.; JeZDIMIROVIC, M.; SMAJIC, M.; STANKOVIC, D.; POPOVIC, S. \& TOMIC, B. Perfil bioquímico de equipos juveniles serbios de fútbol. Int. J. Morphol., 33(2):483-490, 2015.

RESUMEN: El objetivo fue determinar el perfil bioquímico de los equipos juveniles de fútbol nacional y comparar los valores de nueve parámetros bioquímicos entre tres equipos nacionales serbios (menores de 14, 15 y 16 años de edad), así como entre los jugadores de fútbol y no atletas. Ochenta jóvenes jugadores de fútbol y treinta no atletas participaron en el estudio. Se midieron nueve parámetros bioquímicos (glucosa, colesterol, triglicéridos, urea, creatinina, bilirrubina total, AST (SGOT), ALT (SGPT), hierro). Con el fin de determinar la significación de las diferencias entre los grupos en un nivel multivariado se administró un análisis multivariado de varianza (MANOVA), y para poner a prueba las diferencias entre los grupos en un nivel univariado se aplicó un análisis univariado de la varianza (ANOVA). Se encontraron diferencias estadísticamente significativas entre los grupos (jugadores de fútbol hasta 14,15 y 16 años de edad) en un nivel multivariado de las variables bioquímicas (MANOVA, $\mathrm{p}=0,00$ ). ANOVA también reveló diferencias significativas en creatina $(p=0,00)$, la bilirrubina total $(p=0,00)$ y ALT (SGPT) $(p=0,02)$. Se encontraron diferencias estadísticamente significativas en las variables aplicadas entre los jugadores de fútbol y no atletas a nivel multivariado (MANOVA p=0,00). ANOVA también reveló diferencias significativas en glucosa, colesterol, triglicéridos, creatinina, bilirrubina total, ALT (SGPT) y hierro ( $\mathrm{p}=0,00)$ entre los jugadores de fútbol y no atletas. Sin embargo no hubo diferencias estadísticamente significativas en otras variables (AST (SGOT) y urea). Se concluyó que a excepción de la AST (SGOT) y urea no existe diferencia significativa en casi todas las variables (glucosa, colesterol, triglicéridos, etc.) entre los jugadores de fútbol y no atletas. Desde un punto de vista práctico, el médico debe tener en cuenta no solamente la edad, sino también la formación de estado de los individuos en la evaluación de sus análisis de sangre.

PALABRAS CLAVE: Parametros bioquímicos; Selección; Diferencias; Fútbol juvenil.

\section{REFERENCES}

Banfi, G. Biochemical and haematological parameters in football players. In: Volpi, P. Football Traumatology. Current Concepts: from Prevention to Treatment. Milan, Springer-Verlag Mailand, 2006. pp.43-52.

Bangsbo, J. The physiology of soccer--with special reference to intense intermittent exercise. Acta Physiol. Scand. Suppl., 619:1-155, 1994.

Bates, C. J.; Thuman, D. I.; Bingham, S. A.; Margaretts, B. M. \& Nelson, M. (Eds.). Design Concepts in Nutritional Epidemology. New York, Oxford University Press, 1997. pp.170-240.

Bjelica, D.; Popovic. S. \& Petkovic, J. Comparison of instep kicking between preferred and non-preferred leg in young football players. Monten. J. Sports Sci. Med., 2(1):5-10, 2013.

Crespo, R.; Relea, P.; Lozano, D.; Macarro-Sanchez, M.; Usabiaga, J.; Villa, L. F. \& Rico, H. Biochemical markers of nutrition in elite-marathon runners. J. Sports Med. Phys. Fitness, 35(4):268-72, 1995.

Davies, J. A.; Brewer, J. \& Atkin, D. Pre-season physiological characteristics of English first and second division soccer players. J. Sport Sci., 10(6):541-7, 1992.

Dolci, A.; Nanni, G.; Sisca, G.; Costantino, B.; Baldari, A.; Palaia, G.; Banfi, G. Leukocyte counts in professional football players. Haematologica, 88(9):ELT31, 2003.

Domingues, M. Osgood Schlatter's disease - A burst in young football players. Monten. J. Sports Sci. Med., 2(1):23-7, 2013.
Drust, B.; Atkinson, G. \& Reilly, T. Future perspectives in the evaluation of the physiological demands of soccer. Sports Med., 37(9):783-805, 2007.

Durstine, J. L.; Grandjean, P. W.; Davis, P. G.; Ferguson, M. A.; Alderson, N. L. \& Dubose, K. D. Blood lipid and lipoprotein adaptations to exercise: a quantitative analysis. Sports Med., 31(15):1033-62, 2001.

Gräsbeck, R.; Siest, G.; Wilding, P.; Williams, G. Z. \& Whitehead, T. P. Provisional recommendation on the theory of reference values (1978). Part 1. The concept of reference values. Clin. Chem., 25(8):1506-8, 1979.

Hoare, D. G. \& Warr, C. R. Talent identification and women's soccer: an Australian experience. J. Sports Sci., 18(9):751-8, 2000.

Hoff, J.; Wisloff, U.; Engen, L. C.; Kemi, O. J. \& Helgerud, J. Soccer specific aerobic endurance training. Br. J. Sports Med., 36(3):218-21, 2002.

Joksimovic, A.; Stankovic, D.; Ilic, D.; Joksimovic, I.; Jerkan, M. Hematological Profile of Serbian Youth National Soccer Teams. J. Hum. Kinet., 22:51-60, 2009.

LeBlanc, J.; Tremblay, A.; Richard, D. \& Nadeau, A. Daily variations of plasma glucose and insulin in physically-trained and sedentary subjects. Metabolism, 32(6):552-7, 1983.

Lin, L. Y.; Kuo, H. K.; Hwang, J. J.; Lai, L. P.; Chiang, F. T.; Tseng, C. D. \& Lin, J. L. Serum bilirubin is inversely associated with insulin resistance and metabolic syndrome among children and adolescents. Atherosclerosis, 203(2):563-8, 2009. 
Malczewska, J.; Raczynski, G. \& Stupnicki, R. Iron status in female endurance athletes and in non-athletes. Int. J. Sport Nutr. Exerc. Metab., 10(3):260-76, 2000.

Malina, R. M.; Bouchard, C. \& Bar-Or, O. Timing and Sequence of Changes during Adolescence. In: Malina, R.M.; Bouchard, C.; Bar-Or, O. (Eds.). Growth, maturation and physical activity. 2nd ed. Champaign, Human Kinetics, 2004. pp.307-33.

Mangine, R. E.; Noyes, F. R.; Mullen, M. P. \& Barber-Westin, S. D. A physiological profile of the elite soccer athlete. J. Orthop. Sports Phys. Ther., 12(4):147-52, 1990.

Martindale, R. J. J.; Collins, D. \& Daubney, J. Talent development: a guide for practice and research within sport. Quest, 57(4):35375, 2005.

Micoogulları, B. O.; Kirazcı, S. \& Altunsöz, Ö. S. Effects of internal, external and preference of attentional focus feedback instructions on learning soccer "Head Kick". Monten. J. Sports Sci. Med., 1(1):21-6, 2012.

Milanovic, D.; Vuleta, D. \& Sisic, A. Comparative Analysis of morphological characteristics of goalkeepers in football and handball. Monten. J. Sports Sci. Med., 1(1):5-9, 2012.

Nikolaidis, M. G.; Protosygellou, M. D.; Petridou, A.; Tsalis, G.; Tsigilis, N. \& Mougios, V. Hematologic and biochemical profile of juvenile and adult athletes of both sexes: implications for clinical evaluation. Int. J. Sports Med., 24(7):506-11, 2003.

Noakes, T. D. Effect of exercise on serum enzyme activities in humans. Sports Med., 4(4):245-67, 1987.

Philippaerts, R. M.; Vaeyens, R.; Janssens, M.; Van Renterghem, B.; Matthys, D.; Craen, R.; Bourgois, J.; Vrijens, J.; Beunen, G. \& Malina, R. M. The relationship between peak height velocity and physical performance in youth soccer players. $J$. Sports Sci., 24(3):221-30, 2006.

Popovic, S.; Akpinar, S.; Jaksic, D.; Matic, R. \& Bjelica, D. Comparative study of anthropometric measurement and body composition between elite soccer and basketball players. Int. J. Morphol., 31(2):461-7, 2013.

Popovic, S.; Bjelica, D.; Jaksic, D. \& Hadzic, R. Comparative study of anthropometric measurement and body composition between elite soccer and volleyball players. Int. J. Morphol., 32(1):26774, 2014.

Popovic, S.; Bjelica, D.; Petkovic, J. \& Muratovic, A. Comparative Study of Anthropometric Measurement and Body Composition between Elite Soccer and Handball Players. 4th International Scientific Conference "Contemporary Kinesiology". Split, Faculty of Kinesiology, University of Split, 2012. pp.102-8.

Reilly, T.; Clarus, J. \& Stibbe, A. Science and Football II. New York, E. \& F. N. Spon., 1993.
Reilly, T.; Williams, A. M.; Nevill, A. \& Franks, A. A multidisciplinary approach to talent identification in soccer. $J$. Sports Sci., 18(9):695-702, 2000.

Rhodes, E. C.; Mosher, R. E.; McKenzie, D. C.; Franks, I. M.; Potts, J. E. \& Wenger, H. A. Physiological profiles of the Canadian Olympic Soccer Team. Can. J. Appl. Sport Sci., 11(1):31-6, 1986.

Rotenberg, Z.; Seip, R.; Wolfe, L. A. \& Bruns, D. E. "Flipped" patterns of lactate dehydrogenase isoenzymes in serum of elite college basketball players. Clin. Chem., 34(11):2351-4, 1988.

Sarmento, H.; Pereira, A.; Anguera, M.T.; Campaniço, J. \& Leitão, J. The Coaching Process in Football - A qualitative perspective. Monten. J. Sports Sci. Med., 3(1):9-16, 2014.

Stojanovic, M. The field testing of young soccer player. Novi Sad, Sportska asocijacija Novog Sada, 2008.

Svensson, M. \& Drust, B. Testing soccer players. J. Sports Sci., 23(6):601-18, 2005.

Tolfrey, K.; Jones, A. M. \& Campbell, I. G. The effect of aerobic exercise training on the lipid-lipoprotein profile of children and adolescents. Sports Med., 29(2):99-112, 2000.

Vaeyens, R.; Malina, R. M.; Janssens, M.; Van Renterghem, B.; Bourgois, J.; Vrijens, J. \& Philippaerts, R. M. A multidisciplinary selection model for youth soccer: the Ghent Youth Soccer Project. Br. J. Sports Med., 40(11):928-34, 2006.

Weight, L. M.; Klein, M.; Noakes, T. D. \& Jacobs, P. 'Sports anemia'--a real or apparent phenomenon in endurance-trained athletes? Int. J. Sports Med., 13(4):344-7, 1992.

Williams, A. M. \& Franks, A. Talent identification in soccer. Sports Exerc. Inj., 4:159-65, 1998.

Williams, A. M. \& Reilly, T. Talent identification and development in soccer. J. Sports Sci., 18(9):657-67, 2000.

Correspondence to:

Stevo Popovic

University of Montenegro

Faculty for Sport and Physical Education

Narodne omladine bb, 81400 Niksic,

MONTENEGRO

Tel: 00382 (40) 235207

Fax: 00382 (40) 235200

Email: stevop@ac.me
Received: 29-06-2014

Accepted: 20-03-2015 